\title{
Corporate taxation and capital structure: evidence from Russia
}

\section{Evgeny V. Ilyukhin,}

researcher Financial and Business Economics program

York University the Faculty of Liberal Arts and Professional Studies

the Department of Economics: Room 1144, Vari Hall

4700 Keele Street, Toronto, Ontario, M3J 1P3

\begin{abstract}
The study aims to empirically analyze whether corporate taxation has an impact on firm capital structure decisions. The results, based on panel data on Russian private (non-listed), non-financial and non-state owned firms, show that taxation has a significant impact on firm financial leverage (negative in terms of long-term debt and positive in terms of equity). The smallest and largest firms of the sample respond more dramatically to effective tax rates. The results are robust according to the applied tests. Moreover, additional empirical results are obtained for the standard capital structure determinants (size, profitability, tangibility and liquidity of assets), which contribute to capital structure theories.
\end{abstract}

Keywords: corporate income tax, capital structure, leverage, panel data analysis

JEL: G30, G32, H25 


\section{Introduction}

It is interesting that as a capital structure determinant, taxation is the most controversial. Based on the trade-off theory the optimal debt level in a firm's capital structure is defined by the tax shield balance provided by debt and the present value of financial distress costs [Myers, 2003]. More specifically, there is a positive relationship between the corporate tax shield and firm value, assuming that each increase in debt decreases the after-tax cash flow. On the other hand, if an excessive amount of debt is accumulated, an enterprise may default due to the transfer of control to lenders and the incurrence of deadweight costs that further reduce firm value. Therefore, the lower the tax advantages of debt, the lower the optimal debt-to-equity ratio [Frank, Goyal, 2009].

Capital structure decisions are likely to be affected by firm tax payments because corporate taxation typically distinguishes between different sources of financing. Interest payments are generally deducted from taxable profit and are not applicable to equity financing. Given that capital income taxation differentiates between the types of capital, it can be assumed that the tax benefits of different sources of financing affect financial decisions. It therefore has been suggested that corporate profit tax be included in the analysis of the consequences of taxation on capital structure decisions [Graham, 2003].

Empirical research on the capital structure determinants for the firms operating in developing economies, which generally have less efficient capital markets and information asymmetry, as is the case in Russia, is still in demand. In this case, the generally accepted theories could not be fully applied to Russian firms' capital structure. Therefore studying the capital structures determinants of Russian firms is critical as it explains a firm's behavior when making financial decisions. According to many theoretical studies, taxation is considered one of the significant capital structure. Empirical works studying taxation as a determinant of interest based on a sample of Russian firms are not publicly available at present.

\section{Literature Review}

F. Modigliani and M.H. Miller (1958) note that taxation is a reason for preferring debt over equity, which implies the irrelevance of financial decisions for firm value. The value of a permanently levered firm is generated by the value of the corporate tax shield of debt to the value of an identical, unlevered company [Modigliani, Miller, 1963].

There is a theoretical explanation for the existence of a firm-specific optimal debt to equity ratio, which can be reached by taking alternative paths toward reducing the corporate tax burden (e.g., by using depreciation allowances). The marginal personal tax disadvantage is constant while the firm's effective marginal tax rate on interest deductions is dependent on the non-debt tax shield and decreases due to an increase in leverage [DeAngelo, Masulis, 1980].
Empirical evidence comes from a sample of US firms where the probability of preferring debt over equity is analyzed. It was found that losses and investment tax credits diminish the effective tax advantage of debt [MacKie-Mason, 1990]. Another study provides evidence that nondebt tax shields caused by tax shelters are substitutes for debt usage. Of the 76 firms sampled, 38 using tax shelters had debt ratios that were more than 5 percent lower than those of their analogues operating outside of tax shelters [Graham, Tucker, 2006].

A sample of Italian firms was analyzed, employing the variations in additional tax savings caused by differences in profitability or losses [Alworth, Arachi 2001]. The positive impact of higher tax rates on debt usage was detected as well by looking at the regional variation of local German tax rates [Gropp, 2002].

A cross-country study (G-7 countries) found a positive aggregate correlation between net tax advantages and average leverage changes in five countries [Rajan, Zingales, 1995]. Another work demonstrated that the bond issuance locations of US firms are affected by both tax rates and the existence of tax-loss carry-forwards [Newberry, Dhaliwal, 2001]. A positive effect of local tax rates and tax differentials on financial leverage across countries was observed for European multinational affiliations [Huizinga et al., 2008].

The effect of taxation on financing policy using the corporate tax reform (2001) in Croatia as a natural experiment was examined. The findings provide significant evidence that lower taxes affected the capital structure of Croatian firms, which resulted in increased equity levels and decreased long-term debt levels. It was also found that smaller and more profitable firms are more likely to reduce their debt levels. It suggests that lower taxes decrease the incentive to hold onto debt due to decreasing interest tax deductibility [Klapper, Tzioumis, 2008].

The effect of the difference in taxation of debt and equity on capital structures was investigated in another study. The empirical results were based on a panel of European, firm-level data and suggest that a higher tax benefit of debt has a significant positive impact on a firm's financial leverage. The smaller firms respond more dramatically to changes in the tax benefit of debt. The analysis also shows that not only are corporate taxes relevant to corporate financial planning, but variations in capital income tax rates imply significant capital structure adjustments as well. Finally, the relationship between non-debt tax shields and the effect of the corporate tax rate on capital structures was found [Overesch, Voeller, 2008].

The impact of corporate and personal taxes on capital structure was assessed using nearly 500 shifts in statutory corporate and personal income tax rates as natural experiments. The study demonstrated that both corporate and personal income taxes are significant determinants of capital structure. Based on ex post observed summary statistics, across Organisation for Economic Co-Operation and Development (OECD) countries, taxes appear to be as important as other traditional variables in explaining capital structure choices [Faccio, Xu, 2015]. 


\section{Methodology}

The present study's main hypothesis is that taxation affects a firm's capital structure choices due to the decreasing/increasing tax shield benefits on earnings. In particular, the trade-off theory states that a decrease in taxes leads to a reduction in the optimal debt level. The relationship is expected to be stronger for smaller firms, as they have arbitrage opportunities between personal and business taxation as well as a higher probability of bankruptcy compared to larger firms. It is also applicable to more profitable firms due the fact that they are in a better position to repay their debt and use retained earnings as marginal source of funding for investments.

The effective tax rate (EFTR) as the ratio of income tax expense to profit (loss) before taxation is used in order to capture the effect of taxation on the capital structure of the sampled firms. The variable has been widely employed in papers related to taxation research [Buijink et al., 2002; Klapper, Tzioumis, 2008; Shackelford, Shevlin, 2001]. This kind of tax measurement is based on the actual source of financing and the asset structure of individual firms and accounts for the fact that some firms cannot always use all of their allowances against tax. Therefore, it provides a measurement of the actual overall tax burden of Russian firms. In addition, by being firm-specific, the EFTR reflects tax burden changes across the entire corporate sector while the aggregated measurement is supposed to approximate the statutory tax rate.

The following panel data specifications with firm-fixed effects are applied to the study:

$$
Y_{i t}=\mathrm{a}_{i}+\mathrm{b} X_{i t}+\mathrm{g} E F T R_{i t}+\mathrm{e}_{i t} \text {, }
$$

where $Y$ is interchangeably

$$
\frac{\text { Total Debt }}{\text { Assets }}, \frac{\text { Long } \square \text { Term Debt }}{\text { Assets }} \text { and } \frac{\text { Equity }}{\text { Assets }} \text {, }
$$

$\mathrm{a}_{i}$ denotes firm-specific effects, $X$ - a vector of control variables, EFTR - the effective tax rate, $\varepsilon$ - random statistical errors (or disturbances) of the model representing other determinants that influence firm capital structure but have not yet been covered in this study.

A series of control variables that would explain a firm's capital structure are employed in this study as well. Firm size is calculated as the natural logarithm of total assets, which captures the differences in information asymmetry and the costs of financial distress [Bancel, Mittoo, 2004; Klapper et al., 2002]. The ratio of tangible assets to total assets affects the cost of debt because of collateral considerations. It is especially true for transitional economies, where lenders tend to look to the 'hard' financial statement data [Haas et al., 2007]. Return on Assets (profit (loss) before taxation to total assets) and Current Ratio (current assets to current liabilities ratio) measure a firm's cash flows and liquidity, respectively, which influence firm borrowing behaviour. This is due to the fact that firms with poor cash flows and liquidity tend to attract more debt, while the firms with higher profitability can use retained profits and therefore, less external financing [Graham, 2000].

\section{Data}

A sample of private (non-listed), non-financial, nonstate-owned Russian firms from the BvD Ruslana dataset (version: May 2017) is used to study the impact of corporate taxes on capital structure choices. A balanced panel for 2011-2015 that covers the period of constant statutory tax rates was created.

The sample began with 30.480 firm/year observations (5.178 enterprises (25.890 Obs.) have available data for the whole period)). 3.835 observations of financial firms and state-owned enterprises were dropped. Then 5.665 observations of firms with incomplete financial data were excluded from the sample. Given that tax benefits of debt exist only for profitable firms, the sample does not include 3.460 observations from firms with registered losses. Finally, 9.955 observations with a long-term debt to assets ratio of 0-2 percent were dropped. The excluded firms represent enterprises that may not have access to longterm financing (typically very small, recently launched firms) and the changes in debt level due to taxation are unlikely. The final sample includes 2.975 firm-year observations and primarily represents medium and small firms. Firms with registered losses (16.390 Obs.) or with a long-term debt to assets ratio of less than 2 percent (12.930) were included in the sample for the robustness checks of the obtained results.

\section{Results}

\section{Descriptive statistics}

Table 1 presents the summary statistics for both dependent and independent variables used in our calculations. One can find that Russian private non-financial firms are highly indebted on average (46.89 percent for TDBT). The average ratio of long-term debt is 34.49 percent, which is evidence that the main portion of total debt is comprised of long-term debt. It is worth noting that the average tax rate for the sampled firms, which is equal to 16.24 percent, is notably lower than the statutory corporate tax rate over the period (20.00 percent). The reasons for this include the significant variations in tax deductions/credits relevant to specific incentives, accelerated depreciation, tax loss carry provisions and tax penalties 
Table 1

Summary Statistics (2011-2015)

\begin{tabular}{|c|c|c|c|c|c|c|}
\hline Variable & Proxy & Mean & Median & Min & $\operatorname{Max}$ & Std. Dev. \\
\hline Total Debt & TDBT & 0.4689 & 0.4685 & 0.0000 & 0.9881 & 0.2202 \\
\hline Long Term Debt & LDBT & 0.3449 & 0.3079 & 0.02037 & 0.9988 & 0.2203 \\
\hline Equity & EQUT & 0.2444 & 0.2127 & -0.8846 & 3.2234 & 0.2183 \\
\hline Size & SIZE & 8.4465 & 8.3429 & 3.7531 & 13.6496 & 1.3187 \\
\hline Tangibility & TANG & 0.2781 & 0.2207 & 0.0000 & 0.9599 & 0.2518 \\
\hline Return on Assets & PROF & 0.07269 & 0.05144 & 0.0018 & 0.7477 & 0.0949 \\
\hline Current Ratio & CURR & 1.8655 & 1.4705 & 0.0000 & 9.9992 & 1.4020 \\
\hline Effective Tax Rate & EFTR & 0.1624 & 0.1474 & 0.0000 & 1.9568 & 0.1939 \\
\hline
\end{tabular}

\section{Regression results}

Tables 2 and 3 show the results of our calculations for total debt and long-term debt, respectively. The results for total debt are not statistically significant for the full sample while negative sign on significance levels is observed for the size groups (the smallest and largest ones, especially). EFTR is negative and significant, indicating that taxes have a significant negative effect on the leverage of Russian firms in terms of long-term debt. The interactions of EFTR with firm size and profitability changed the signs, but they are not statistically significant. It can be assumed that the effect of corporate taxes increases with the applied measures. The calculations for two size groups demonstrate that the effect is significant for the size categories mentioned above in the case of total debt. The results for the fourth group do not support the hypothesis that the larger firms are less sensitive to taxation because of more tax exemptions, deductions and allowances [Kesner-Skreb et al., 2003 Klapper, Tzioumis, 2008].

Table 2

Regression Results of the Total Debt to Assets Ratio

\begin{tabular}{|c|c|c|c|c|c|c|c|}
\hline \multirow{3}{*}{ Variables } & \multicolumn{7}{|c|}{ Total Debt to Assets Ratio } \\
\hline & \multicolumn{3}{|c|}{ Full Sample } & \multirow{2}{*}{$\frac{\mathrm{Q} 1}{(4)}$} & \multirow{2}{*}{$\frac{\mathrm{Q}^{2}}{(5)}$} & \multirow{2}{*}{$\frac{\mathrm{Q} 3}{(6)}$} & \multirow{2}{*}{$\frac{\mathrm{Q} 4}{(7)}$} \\
\hline & (1) & $(2)$ & (3) & & & & \\
\hline \multirow[t]{2}{*}{ const } & $0.469^{* * *}$ & $0.468^{\star * *}$ & $0.468^{\star * *}$ & $0.467^{\star * *}$ & 0.140 & 0.233 & $0.666^{* * *}$ \\
\hline & $(0.003)$ & $(0.003)$ & $(0.003)$ & $(0.091)$ & $(0.263)$ & $(0.258)$ & $(0.106)$ \\
\hline \multirow[t]{2}{*}{ SIZE } & 2.063 & 8.512 & 8.852 & -0.004 & 0.039 & 0.033 & -0.015 \\
\hline & $(0.000)$ & $(0.000)$ & $(0.003)$ & $(0.013)$ & $(0.033)$ & $(0.029)$ & $(0.010)$ \\
\hline \multirow[t]{2}{*}{ TANG } & 0.000 & 0.000 & 0.000 & 0.049 & $0.064^{\star}$ & 0.039 & $0.057^{\star \star}$ \\
\hline & $(0.002)$ & $(0.002)$ & $(0.002)$ & $(0.040)$ & $(0.033)$ & $(0.032)$ & $(0.029)$ \\
\hline \multirow[t]{2}{*}{ PROF } & -0.001 & -0.001 & -0.000 & $-0.565^{\star \star \star}$ & $-0.548^{\star * *}$ & $-0.587^{\star * *}$ & $-0.498^{\star \star *}$ \\
\hline & $(0.004)$ & $(0.004)$ & $(0.005)$ & $(0.084)$ & $(0.078)$ & $(0.081)$ & $(0.098)$ \\
\hline \multirow[t]{2}{*}{ CURR } & -8.735 & -8.581 & -8.605 & $0.040^{* * *}$ & $0.012^{\star *}$ & 0.001 & 0.000 \\
\hline & $(0.000)$ & $(0.000)$ & $(0.000)$ & $(0.006)$ & $(0.005)$ & $(0.006)$ & $(0.006)$ \\
\hline \multirow[t]{2}{*}{ EFTR } & 0.001 & 0.004 & 0.004 & $-0.098^{\star * *}$ & 0.044 & $-0.073^{\star}$ & $-0.214^{\star \star \star \star}$ \\
\hline & $(0.002)$ & $(0.012)$ & $(0.012)$ & $(0.042)$ & $(0.040)$ & $(0.039)$ & $(0.042)$ \\
\hline
\end{tabular}




\begin{tabular}{|c|c|c|c|c|c|c|c|}
\hline \multirow{3}{*}{ Variables } & \multicolumn{7}{|c|}{ Total Debt to Assets Ratio } \\
\hline & \multicolumn{3}{|c|}{ Full Sample } & \multirow{2}{*}{$\frac{\mathrm{Q} 1}{(4)}$} & \multirow{2}{*}{$\begin{array}{l}\text { Q2 } \\
(5)\end{array}$} & \multirow{2}{*}{$\frac{\mathrm{Q} 3}{(6)}$} & \multirow{2}{*}{$\frac{\mathrm{Q} 4}{(7)}$} \\
\hline & (1) & $(2)$ & (3) & & & & \\
\hline EFTR $x$ & - & -0.000 & -0.000 & - & - & - & - \\
\hline SIZE & & $(0.001)$ & $(0.001)$ & & & & \\
\hline EFTR $x$ & - & - & -0.003 & - & - & - & - \\
\hline PROF & & & $(0.026)$ & & & & \\
\hline $\mathrm{N}$ & 2975 & 2975 & 2975 & 743 & 744 & 744 & 744 \\
\hline $\mathrm{R}^{2}$ (within) & 0.001 & 0.001 & 0.001 & 0.112 & 0.072 & 0.073 & 0.064 \\
\hline
\end{tabular}

Notes: Fixed-effects regressions for a balanced panel of private, non-state, non-financial Russian firms over the period 2011-2015. Standard errors are shown in parentheses. ${ }^{*} p<0.10 ;{ }^{* *} p<0.05 ;{ }^{* *} p<0.01$. Four size groups' (quartiles) results are based on firms' total asset values, which are presented in Columns 4-7.

Table 3

Regression Results of the Long-Term Debt to Assets Ratio

\begin{tabular}{|c|c|c|c|c|c|c|c|}
\hline \multirow{3}{*}{ Variables } & \multicolumn{7}{|c|}{ Long-Term Debt to Assets Ratio } \\
\hline & \multicolumn{3}{|c|}{ Full Sample } & \multirow{2}{*}{$\begin{array}{l}\text { Q1 } \\
(4)\end{array}$} & \multirow{2}{*}{$\frac{\mathrm{Q} 2}{(5)}$} & \multirow{2}{*}{$\frac{\mathrm{Q3}}{(6)}$} & \multirow{2}{*}{$\frac{\mathrm{Q} 4}{(7)}$} \\
\hline & (1) & $(2)$ & (3) & & & & \\
\hline \multirow[t]{2}{*}{ const } & $0.247^{\star * *}$ & $0.252^{\star * \star}$ & 0.254 & $0.452^{\star * \star}$ & 0.317 & 0.258 & $0.331^{* * *}$ \\
\hline & $(0.018)$ & $(0.024)$ & $(0.024)$ & $(0.089)$ & $(0.244)$ & $(0.246)$ & $(0.101)$ \\
\hline \multirow[t]{2}{*}{ SIZE } & 0.001 & 0.001 & 0.001 & $-0.031^{\star *}$ & -0.012 & 0.004 & -0.001 \\
\hline & $(0.002)$ & $(0.003)$ & $(0.003)$ & $(0.013)$ & $(0.031)$ & $(0.028)$ & $(0.010)$ \\
\hline \multirow[t]{2}{*}{ TANG } & $0.087^{* * *}$ & $0.086^{* * *}$ & 0.087 & $0.087^{\star *}$ & $0.153^{* * *}$ & $0.144^{* * *}$ & $0.167^{* * *}$ \\
\hline & $(0.011)$ & $(0.011)$ & $(0.011)$ & $(0.039)$ & $(0.031)$ & $(0.030)$ & $(0.027)$ \\
\hline \multirow[t]{2}{*}{ PROF } & $-0.134^{* * *}$ & $-0.134^{* \star *}$ & -0.154 & $-0.491^{* * *}$ & $-0.497^{* * *}$ & $-0.663^{* * *}$ & $-0.428^{\star * *}$ \\
\hline & $(0.029)$ & $(0.030)$ & $(0.037)$ & $(0.082)$ & $(0.072)$ & $(0.078)$ & $(0.094)$ \\
\hline \multirow[t]{2}{*}{ CURR } & $0.042^{* * *}$ & $0.042^{* * *}$ & 0.042 & $0.072^{* * *}$ & $0.050^{* * *}$ & $0.041^{* * *}$ & $0.028^{* * *}$ \\
\hline & $(0.002)$ & $(0.002)$ & $(0.002)$ & $(0.006)$ & $(0.005)$ & $(0.006)$ & $(0.006)$ \\
\hline \multirow[t]{2}{*}{ EFTR } & $-0.037^{\star * \star}$ & -0.067 & -0.077 & $-0.102^{\star *}$ & -0.024 & -0.045 & $-0.216^{* * *}$ \\
\hline & $(0.014)$ & $(0.087)$ & $(0.088)$ & $(0.041)$ & $(0.037)$ & $(0.037)$ & $(0.040)$ \\
\hline EFTR $x$ & - & 0.004 & 0.005 & - & - & - & - \\
\hline SIZE & & $(0.010)$ & $(0.010)$ & & & & \\
\hline EFTR $x$ & - & - & 0.164 & - & - & - & - \\
\hline PROF & & & $(0.188)$ & & & & \\
\hline $\mathrm{N}$ & 2975 & 2975 & 2975 & 743 & 744 & 744 & 744 \\
\hline $\mathrm{R}^{2}$ (within) & 0.168 & 0.169 & 0.169 & 0.215 & 0.172 & 0.133 & 0.102 \\
\hline
\end{tabular}

Note: see notes for Table 2. 
Regarding the control variables, it was found that firm performance measured by return on assets negatively affects a firm's long-term debt. This indicates that firms prefer to fund themselves internally using retained earnings. Moreover, firm liquidity and the tangibility of assets are positively related to the long-term debt to assets ratio, because firms with higher values of these aforementioned measurements have easier access to debt, while the firm size coefficients are not statistically significant.

The equity to assets ratio as a dependent variable is employed to support the results of the debt estimates. It is equivalent to using a variable for total liabilities to assets, which is a broader measurement for borrowing that incorporates nondebt liabilities with tax-relief capacities and short-term debt [Klapper, Tzioumis, 2008].

The results in Table 4 demonstrate a significant positive relationship between EFTR and equity levels. It is confirmed by statistically significant coefficients with the same signs for all size groups. The interaction term values are not significant. All control variables are positive and significant.

Table 4

Regression Results of the Equity to Assets Ratio

\begin{tabular}{|c|c|c|c|c|c|c|c|}
\hline \multirow{3}{*}{ Variables } & \multicolumn{7}{|c|}{ Equity to Assets Ratio } \\
\hline & \multicolumn{3}{|c|}{ Full Sample } & \multirow{2}{*}{$\frac{\mathrm{Q} 1}{(4)}$} & \multirow{2}{*}{$\frac{\mathrm{Q} 2}{(5)}$} & \multirow{2}{*}{$\frac{\mathrm{Q3}}{(6)}$} & \multirow{2}{*}{$\frac{\mathbf{Q} 4}{(7)}$} \\
\hline & (1) & (2) & (3) & & & & \\
\hline \multirow[t]{2}{*}{ const } & $-0.130^{\star * \star}$ & $-0.137^{\star \star *}$ & $-0.134^{\star \star \star}$ & $-0.177^{\star \star \star}$ & 0.033 & 0.013 & $-0.182^{\star *}$ \\
\hline & $(0.021)$ & $(0.027)$ & $(0.027)$ & $(0.068)$ & $(0.230)$ & $(0.264)$ & $(0.093)$ \\
\hline \multirow[t]{2}{*}{ SIZE } & $0.022^{* * *}$ & $0.023^{* * *}$ & $0.023^{\star * *}$ & $0.034^{* * *}$ & 0.002 & 0.000 & $0.026^{\star * *}$ \\
\hline & $(0.002)$ & $(0.003)$ & $(0.003)$ & $(0.009)$ & $(0.029)$ & $(0.030)$ & $(0.009)$ \\
\hline \multirow[t]{2}{*}{ TANG } & $0.243^{\star * *}$ & $0.243^{* * *}$ & $0.243^{\star * *}$ & $0.226^{\star * *}$ & $0.231^{\star * *}$ & $0.206^{\star * *}$ & $0.138^{\star \star *}$ \\
\hline & $(0.013)$ & $(0.013)$ & $(0.013)$ & $(0.030)$ & $(0.029)$ & $(0.032)$ & $(0.025)$ \\
\hline \multirow[t]{2}{*}{ PROF } & $0.418^{\star * *}$ & $0.418^{\star * *}$ & $0.388^{\star * *}$ & $0.537^{\star * *}$ & $0.807^{\star * *}$ & $0.792^{\star * *}$ & $0.626^{* * *}$ \\
\hline & $(0.033)$ & $(0.033)$ & $(0.042)$ & $(0.062)$ & $(0.068)$ & & $(0.086)$ \\
\hline \multirow[t]{2}{*}{ CURR } & $0.042^{\star * *}$ & $0.042^{* * *}$ & $0.042^{\star * \star}$ & $0.013^{\star * \star}$ & $0.038^{\star \star *}$ & $0.056^{\star * *}$ & $0.036^{\star * *}$ \\
\hline & $(0.002)$ & $(0.002)$ & $(0.002)$ & $(0.004)$ & $(0.005)$ & $(0.006)$ & $(0.005)$ \\
\hline \multirow[t]{2}{*}{ EFTR } & $0.070^{\star * \star}$ & 0.108 & 0.093 & $0.104^{\star \star \star}$ & $0.059^{\star}$ & $0.077^{\star}$ & $0.229^{\star * *}$ \\
\hline & $(0.016)$ & $(0.098)$ & $(0.099)$ & $(0.031)$ & $(0.035)$ & $(0.040)$ & $(0.037)$ \\
\hline EFTR $x$ & - & -0.004 & -0.003 & - & - & - & - \\
\hline SIZE & & $(0.011)$ & $(0.011)$ & & & & \\
\hline EFTR $x$ & - & - & 0.254 & - & - & - & - \\
\hline PROF & & & $(0.212)$ & & & & \\
\hline $\mathrm{N}$ & 2975 & 2975 & 2975 & 743 & 744 & 744 & 744 \\
\hline $\mathrm{R}^{2}$ (within) & 0.319 & 0.319 & 0.319 & 0.193 & 0.309 & 0.255 & 0.200 \\
\hline
\end{tabular}

Note: see notes for Table 2.

The regressions were run again, including the firms with negative returns as well as the firms with a long-term debt ratio of 0-2 percent that were excluded from the initial calculations (Table 5). It was found that the signs of statistically significant coefficients for the sample, including the firms with positive returns only, are the same. This demonstrates the apparent effect of taxation on the debt and equity of Russian firms. 
Table 5

Robustness Check

\begin{tabular}{|c|c|c|c|c|c|c|}
\hline \multirow{2}{*}{ Variables } & \multicolumn{2}{|c|}{ Total Debt/Assets } & \multicolumn{2}{|c|}{ Long-Term Debt/Assets } & \multicolumn{2}{|c|}{ Equity/Assets } \\
\hline & (1) & (2) & (3) & (4) & (5) & (6) \\
\hline \multirow[t]{2}{*}{ const } & $0.248^{\star * *}$ & $0.227^{\star * *}$ & -0.017 & $-0.050^{* * *}$ & $-0.092^{\star * \star}$ & $-0.070^{* * *}$ \\
\hline & $(0.014)$ & $(0.013)$ & $(0.011)$ & $(0.010)$ & $(0.012)$ & $(0.011)$ \\
\hline \multirow[t]{2}{*}{ SIZE } & 0.002 & $0.006^{\star * *}$ & $0.011^{\star * *}$ & $0.014^{\star * \star}$ & $0.017^{\star \star *}$ & $0.013^{\star * *}$ \\
\hline & $(0.002)$ & $(0.002)$ & $(0.001)$ & $(0.001)$ & $(0.002)$ & $(0.001)$ \\
\hline \multirow[t]{2}{*}{ TANG } & $0.213^{\star * *}$ & $0.234^{\star \star *}$ & $0.204^{* * *}$ & $0.239^{* * *}$ & $0.338^{\star * *}$ & $0.309^{\star * *}$ \\
\hline & $(0.012)$ & $(0.011)$ & $(0.009)$ & $(0.008)$ & $(0.010)$ & $(0.009)$ \\
\hline \multirow[t]{2}{*}{ PROF } & $-0.416^{* * *}$ & $-0.444^{\star * *}$ & $-0.276^{\star * *}$ & $-0.298^{\star * *}$ & $0.520^{\star * *}$ & $0.568^{\star * *}$ \\
\hline & $(0.016)$ & $(0.014)$ & $(0.012)$ & $(0.011)$ & $(0.014)$ & $(0.012)$ \\
\hline \multirow[t]{2}{*}{ CURR } & -0.001 & -0.000 & $0.032^{* * *}$ & $0.037^{\star * *}$ & $0.080^{\star * *}$ & $0.081^{\star \star \star}$ \\
\hline & $(0.002)$ & $(0.002)$ & $(0.001)$ & $(0.001)$ & $(0.002)$ & $(0.002)$ \\
\hline \multirow[t]{2}{*}{ EFTR } & $-0.016^{* * *}$ & 0.003 & $-0.009^{\star *}$ & 0.001 & $0.017^{\star * *}$ & 0.001 \\
\hline & $(0.006)$ & $(0.005)$ & $(0.004)$ & $(0.004)$ & $(0.005)$ & $(0.004)$ \\
\hline $\mathrm{N}$ & 12930 & 16390 & 12930 & 16390 & 12930 & 16390 \\
\hline $\mathrm{R}^{2}$ & 0.078 & 0.089 & 0.116 & 0.136 & 0.340 & 0.318 \\
\hline
\end{tabular}

Note: OLS regressions. Firms with negative returns are included while their EFTR values equal to 0 (Columns 2, 4 and 6). Firms with ratios of long-term debt/assets of 0-2\% are included as well (Columns 1, 3 and 5). See also notes for Table 2.

\section{Conclusions}

The study proposes that corporate taxation has a significant impact on the capital structure of Russian private (non-listed), non-financial and non-state-owned firms. The effect was negative for debt in terms of the long-term debt to assets ratio, while it was positive for the equity to assets ratio. Considering the period of constant statutory tax rates, the study provides strong evidence of the effect of taxation on a given firm's financing policy. These findings are not consistent with the trade-off theory of capital structure that predicts higher leverage when a firm is forced to pay higher taxes on its earnings. The negative effect of taxes on leverage is supported by some empirical studies, especially those on emerging economies [e.g., Anh, Yen, 2014]. In addition, the statistically significant relationships between debt/equity measurements and firm size, performance and liquidity demonstrate that firm-specific effects may also influence the rate of adjustment and explain variations across firms [Flannery, Rangan, 2006].

\section{References}

Alworth J., Arachi G. (2001) The effect of taxes on corporate financing decisions: Evidence from a panel of Italian firms. International Tax and Public Finance, vol. 8, no. 4, pp. 353-376.

Anh D.T.Q., Yen Q.T.H. (2014) The factors affecting capital structure of listed firms on Ho Chi Minh Stock Exchange (HOSE). Journal of Development and Integration, vol. 18 , no. 28 , pp. 34-39.

Bancel F., Mittoo U.R. (2004) Cross-country determinants of capital structure choice: A survey of European firms. Financial Management, vol. 33, no. 4, pp. 103-132.

Buijink W., Janssen B., Schols Y. (2002) Evidence of the effect of domicile on corporate average effective tax rates in the European Union. Journal of International Accounting, Auditing \& Taxation, vol. 11, no. 2, pp. 115-130. 
DeAngelo H., Masulis R.W. (1980) Optimal capital structure under corporate and personal taxation. Journal of Financial Economics, vol. 8, no. 1, pp. 3-29.

Faccio M., Xu J. (2015) Taxes and capital structure. Journal of Financial and Quantitative Analysis, vol. 50, no. 3, pp. 277-300.

Flannery M.J., Rangan K.P. (2006) Partial adjustment toward target capital structures. Journal of Financial Economics, vol. 79, no. 3, pp. 469-506.

Frank M.Z., Goyal V.K. (2009) Capital structure decisions: Which factors are reliably important? The Journal of Financial Management, vol. 38, no. 1, pp. 1-37.

Graham J.R. (2000) How big are the tax benefits of debt? Journal of Finance, vol. 55, no. 5, pp. 1901-1941.

Graham J.R. (2003) Taxes and corporate finance: A review. Review of Financial Studies, vol. 16, no. 4, pp. 1074-1128.

Graham J.R., Tucker A. (2006) Tax shelters and corporate debt policy. Journal of Financial Economics, vol. 81, no. 3, pp. 563-594.

Gropp R.E. (2002) Local taxes and capital structure choice. International Tax and Public Finance, vol. 9, no. 1, pp. 51-71.

Haas R., Ferreira D., Taci A. (2007) What determines banks' customer choice? Evidence from transition countries. EBRD Working Paper Series, no. 104.

Huizinga H., Laeven L., Nicodeme G. (2008) Capital structure and international debt shifting. Journal of Financial Economics, vol. 88, no. 1, pp. 80-118.

Kesner-Skreb M., Plese I., Mikić M. (2003) State aid to enterprises in Croatia in 2001. Institute of Public Finance, no. 18.

Klapper L.F., Sarria-Allende V., Sulla V. (2002) SME financing in Eastern Europe. World Bank Policy Research Working Paper Series, no. 2933.

Klapper L.F., Tzioumis K. (2008) Taxation and capital structure: Evidence from a transition economy. Hellenic Observatory Papers on Greece and Southeast Europe, no. 16.

MacKie-Mason J.K. (1990) Do taxes affect corporate financing decisions? Journal of Finance, vol. 45, no. 5, pp. 1471-1493.

Modigliani F., Miller M.H. (1963) Corporate income taxes and the cost of capital: A correction. American Economic Review, vol. 53, no. 3, pp. 433-443.

Modigliani F., Miller M.H. (1958) The cost of capital, corporate finance, and the theory of investment. American Economic Review, vol. 48, no. 3, pp. 261-297.
Myers S.C. (2003) Financing of corporations. Handbook of the Economics of Finance, Chapter 14, North-Holland, Amsterdam, pp. 215-253.

Newberry K., Dhaliwal D.S. (2001) Cross-jurisdictional income shifting by U.S. multinationals: Evidence from international bond offerings. Journal of Accounting Research, vol. 39, no. 3, pp. 643-662.

Overesch M., Voeller D. (2008) The impact of personal and corporate taxation on capital structure choices. Centre for European Economic Research, discussion paper no. $08-020$.

Rajan R.G., Zingales L. (1995) What do we know about capital structure? Some evidence from international data. Journal of Finance, vol. 50, no. 5, pp. 1421-1460.

Shackelford D.A., Shevlin T. (2001) Empirical tax research in accounting. Journal of Accounting and Economics, vol. 31, no. 1-3, pp. 321-387. 